\title{
耳下腺乳頭状囊胞腺癌の副咽頭間隙進展例
}

\author{
井口 芳明・平山 方俊 ・ 山本 一博 \\ 橋本 大門 $\cdot$ 中山 明化* 落合 敦*
}

\section{A Case of Papillary Cystadenocarcinoma in the Parapharyngeal Space Originating from the Parotid Gland}

\author{
Yoshiaki Iguchi, Masatoshi Hirayama, Kazuhiro Yamamoto and Daimon Hashimoto \\ (Yokosuka Shimin Hospital) \\ Meijin Nakayama and Atsushi Ochiai \\ (Kitasato University)
}

\begin{abstract}
We report a case of high-grade papillary cystadenocarcinoma in the parapharyngeal space that we considered originated from the parotid gland. The patient was a 52 -year-old man with a chief complaint of unilateral earache and MRI revealed a parapharyngeal tumor. The tumor was removed and postoperative radiation and chemotherapy were performed but local recurrences were found 1 month later. Although we first considered that the tumor was a low-grade malignancy, it was highly malignant.
\end{abstract}

Key words : papillary cystadenocarcinoma, parotid gland, parapharyngeal tumor

\section{はじめに}

Papillary cystadenocarcinoma は1991年に WHO によ り新たに病理組織学上分類された唾液腺癌の一つであり, 病理組織学的に低悪性度で臨床的にも低悪性度とされて (る12). この腫瘍の概念が比較的新しいことによりそ の報告はまだ少なく，また以前に報告された耳下腺腫瘍 例のなかには本腫瘍に該当する症例もあるといわれてい る3)。今回われわれは副咽頭間隙に進展した耳下腺深葉 原発と思われ，治療に抵抗した悪性度が高いと思われた papillary cystadenocarcinoma の 1 例を経験したので文 献的考察を加兄報告する.

\section{症例}

症例は52歳の男性で, 主訴は耳痛である。現病歴は, 平成11年 9 月頃より右耳痛が出現し近医で加療されてい
たが，治瘉しないため平成 12 年 4 月 17 日に紹介されて当 科を受診した. 右外耳道, 鼓膜所見に異常はなく, 頸部 腫瘤はなかった。その他の耳鼻咽喉頭所見に異常はな かった． 既往歴や家族歴に特記すべき事項はなかった. 耳下部の超音波検査を行ったが腫瘍を思わせる所見は はっきりしなかった. その後開口制限がみられるように なり耳痛も続くため，5月16日にMRIを施行したとこ 万右副咽頭間隙に $\mathrm{T} 1$ 強調画像で低信号, T2 強調画像 で高信号を示す腫瘤陰影が認められた（図 1 )。ガリウム シンチグラフィーでは右副咽頭間隙に一致して強い集積 が認められた. 水平断単純 CT では右耳下腺深葉と連続 性があるようにみえる副咽頭間隙腫瘍が認められた（図 2 ). 術前の針生検は行わなかった. 以上の所見から右 副咽頭間隙悪性腫瘍と診断乙，拡大手術も考慮し準備し た上で，6月20日に全身麻酔下で腫瘍摘出術を施行した. 


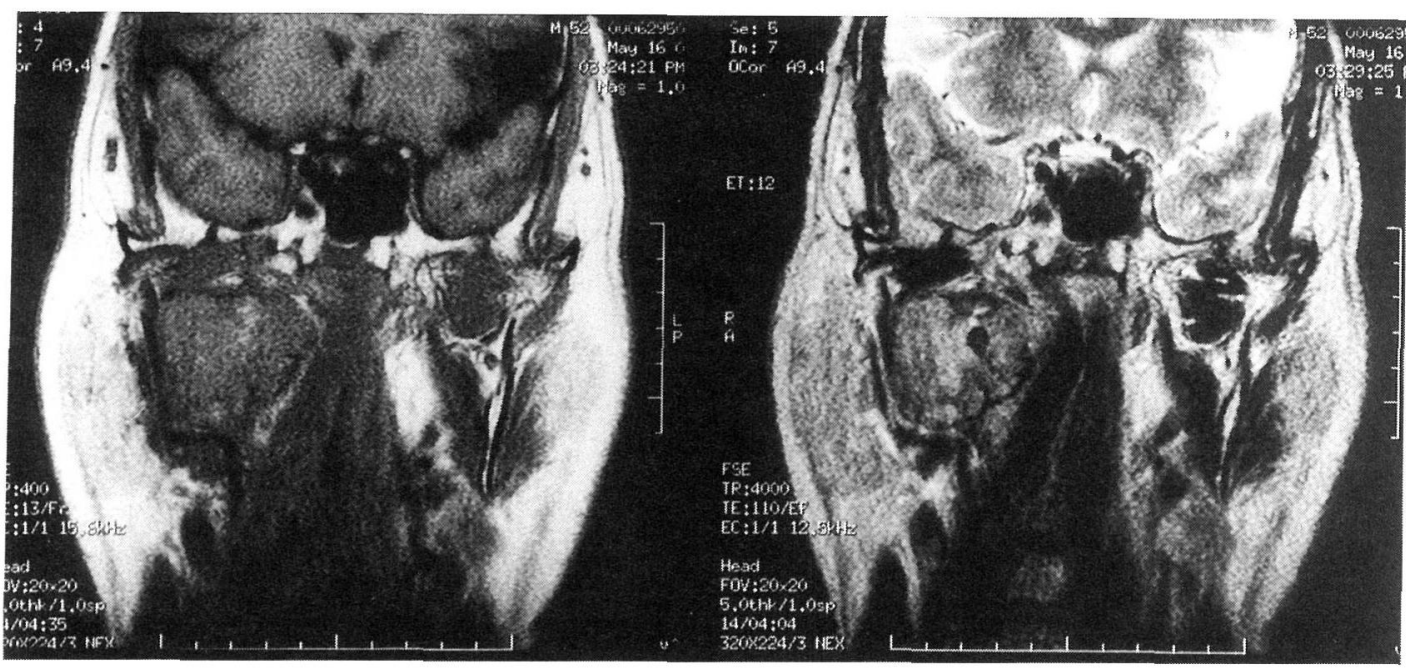

図 1 MRI 所見

左に前額断 $\mathrm{T} 1$ 強調画像, 右に $\mathrm{T} 2$ 強調画像を示寸. T1 強調画像で低信号, T2 強調画像で高信号 を示す右副咽頭間隙腫瘍を認める.

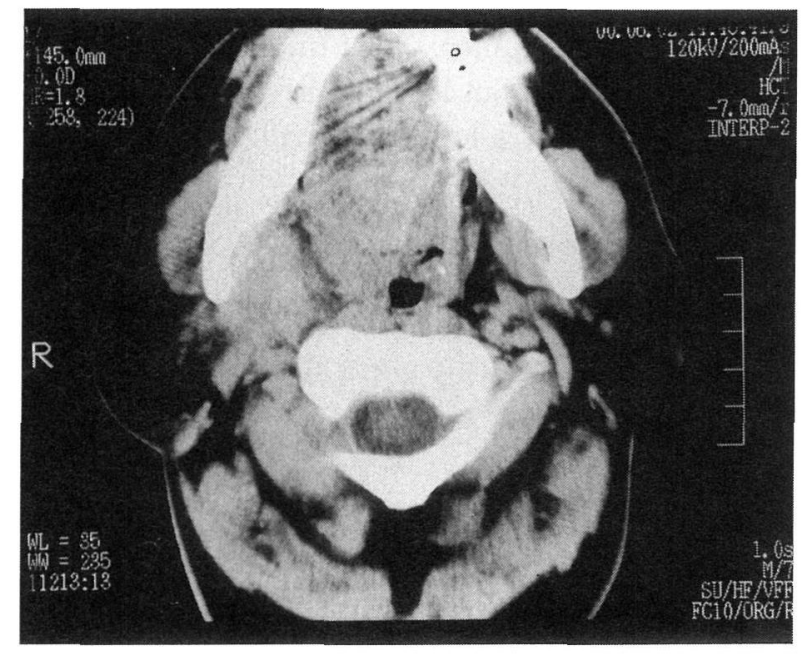

図 2 初診時水平断単純 $\mathrm{CT}$ 所見

右耳下腺深葉と連続性があるよらにみ劣る副咽頭間隙腫 瘍を認める。

経耳下腺・頸部切開法に準じた皮膚切開をし，耳下腺浅 葉を剥離し顔面神経を主幹より同定し保存した。経耳下 腺的に腫瘍に到達でさないため，下顎部の頸部切開から 腫瘍にアプローチした，腫瘍は，上方は頭蓋底，下方は 下顎骨，側方は耳下腺深葉に接していたが，腫瘍表面は 平滑であり周囲との癒着はなく容易に用手剥離できた。 本手術で根治性が得られると考兄耳下腺全摘などの桩大
手術は行わなかった。術中迅速病理検査は容易に腫瘍が 摘出できたことから行わなかった．咽頭傍の操作で術後 浮腫が必発と考光, 気管切開術を施行し手術を終了した. 摘出物と乞の割面を図 3 に示す. 摘出材料の病理組織学 的検査の結果は papillary cystadenocarcinoma であった (図 4 ). 以上の所見から耳下腺深葉原発の悪性腫瘍が副 咽頭間隙に進展したと思われた。本腫瘍は悪性腫瘍であ り，切除断端も不十分と考光，追加治療として放射線（リ ニアック)を右耳下腺に 7 月 3 日から 8 月15日まで 60 Gy, 同期間にフルオウラシル (UFT) $300 \mathrm{mg} /$ 日の内服 を行った. 顔面神経下顎枝の一過性の軽度麻痺があった が，気管切開孔を閉鎖し8月25日に退院した。

その後外来で週に 1 回経過をみていたが，9月25日に 前回の手術創部に一致した右顎下部の腫瘤を認め, 増大 してきたので10月 5 日に再入院した。再入院時の右下顎 部所見 (図 5 ), 水平断 CT (図 6 ) 走示す. 腫瘍の再発と 診断し下顎骨離断を含めた拡大手術, 皮弁による皮膚再 建の準備のもと，10月 6 日飞全身麻酔下で右耳下腺拡大 全摘, 右顎下部腫瘍摘出, 右頸部郭清術を施行した. 手 術所見では，右顎下腺に接して耳下部にかけて大きな腫 瘍が多数存在し，下顎皮虐への腫瘍直接浸潤が認められ た。下顎骨への腫瘍浸潤は認めなかった。腫瘍上方は顎 関節に接していた.耳下腺は放射線の影響で線維化して いた。胸鎖乳突筋や内頸静脈に沿うリンパ節の腫脹は認 めなかった。耳下腺を全摘出し顎下部の腫瘍を同部の皮 

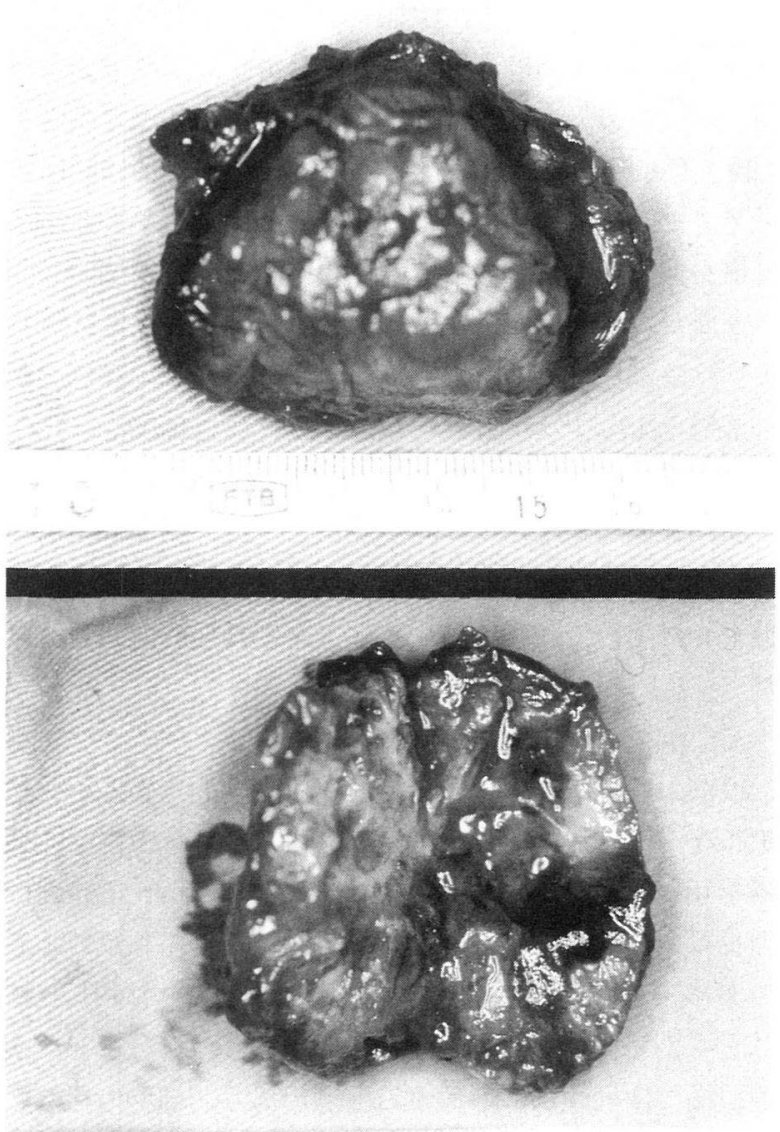

図 3 摘出物之割面

摘出物は $60 \times 26 \times 22 \mathrm{~mm}$ の腫瘍である(上段)。割面で は一部整胞状で大部分は充実性である(下段).

膚をつけて一塊として摘出した，皮䖉は縫い合わせるこ とができたので皮弁は必要なかった，摘出材料の病理組 織学的検査では前回と同様の papillary cystadenocarcinoma であった、腫瘍マーカーであるCEA は頻回測定したが $0.5 \mathrm{ng} / \mathrm{ml}$ 以下で正常であった．術後治療として下顮部 にリニアック $40 \mathrm{~Gy}$ を照射し，ネダプラチン(アクプラ) $100 \mathrm{mg}$ 老 2 クール行った。平成13年 1 月現在，右耳周 囲に腫瘍の再発を認め, 頭蓋内病変について検索中であ る.

\section{考察}

1. 副咽頭間隙腫瘍について

副咽頭間隙は咽頭側方の上方は頭蓋底，下方は舌骨に 位置した逆ピラミッド型の潜在腔である．副咽頭間隙に
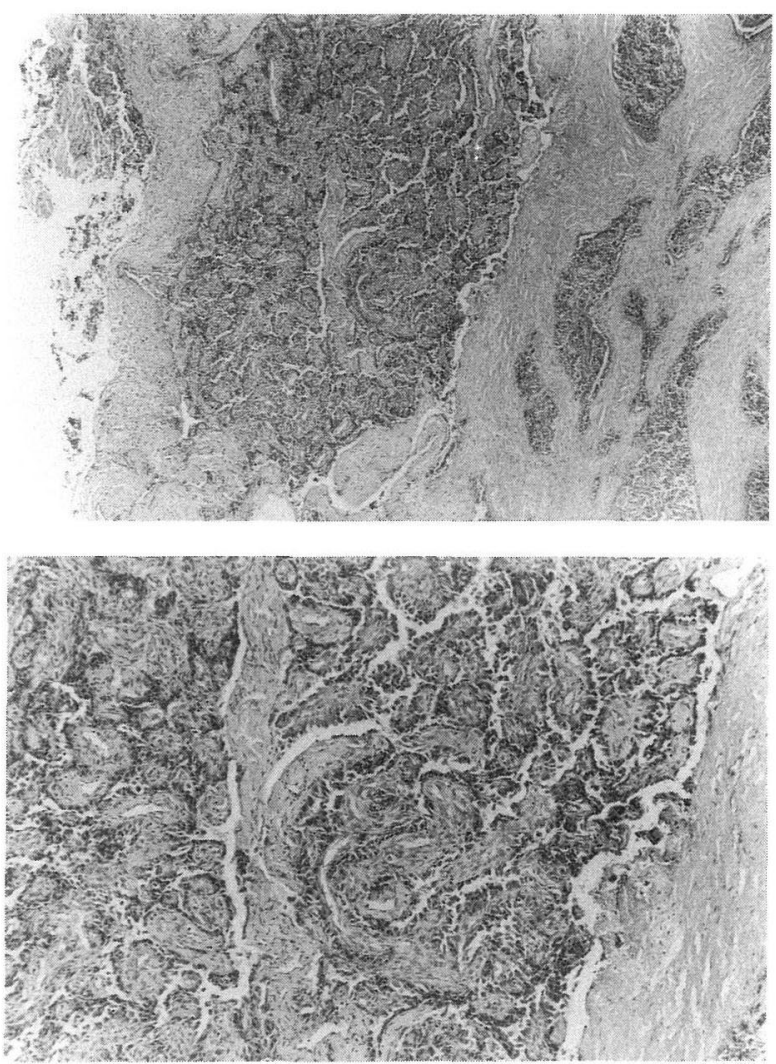

図 4 病理組織像 (HE 染色 上段40倍, 下段100倍)

腫瘍は血管間質を軸として乳頭状に增殖する腫瘍であ り, papillary cystadenocarcinoma と診断した. 本症例 の病理所見では腫瘍の蜂巣状の発育が目立ち, 囊胞の形 成は少ない，腫瘍細胞は核が目立ち膿染されている。

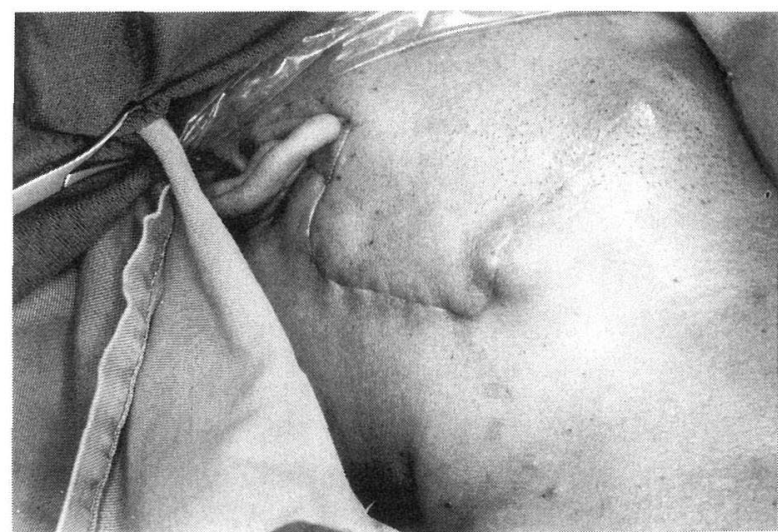

図 5 再入院時の右下顎部の所見 右下㴿部の前回手術創飞沿って腫瘤を認め, 皮店への浸 潤が疑われる。 


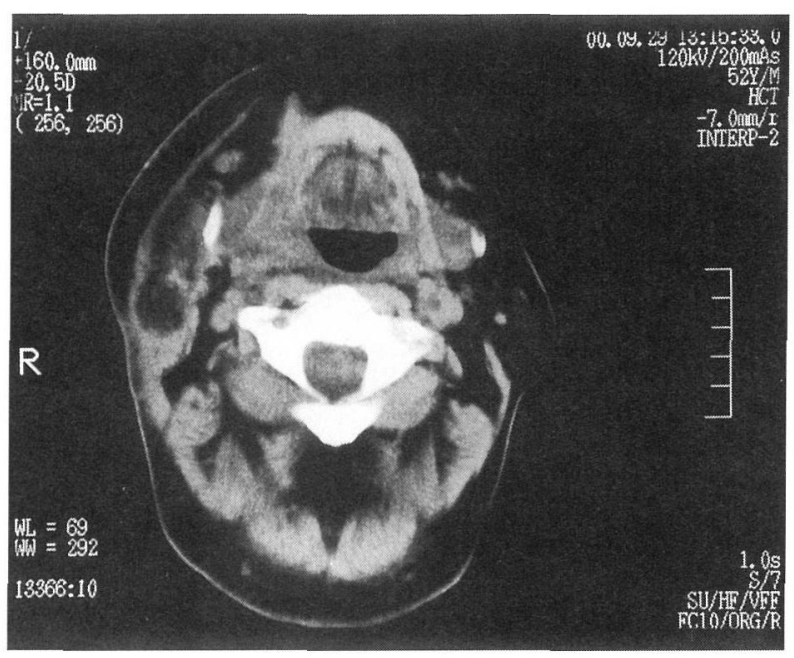

図 6 再発時の水平断 CT 所見

右下顎部に腫瘤を認め, 䨢胞を形成しているようにみ兄 る.

発生した腫瘍の診断は画像診断学の発達に伴い容易々 なってきたが，その際副咽頭間隙原発腫瘍と耳下腺腫瘍 との鑑別が必要である.Som ら4) とよれば耳下腺と副 咽頭間隙の双方の読影が重要であり，CT 所見で耳下腺 之副咽頭間隙とのあいだに連続性があれば耳下腺腫瘍,

間隙があれば副咽頭間隙原発の腫瘍之診断するとしてお り，本例では CT 所見上連続性を認めたので，耳下腺深 葉から副咽頭間隙に進展した腫瘍と思われた。また， Som ら新の報告の時点では MRIがなかったためCT 上 での診断としているが，今回 MRIでもとの情報は得ら れると考光られた。

副咽頭間隙に発生する腫瘍は, Hughes ら5) そよれば $80 \%$ が良性腫瘍であり，そのなかで多形腺腫が $50 \%$, 傍 神経節腫が $25 \%$, 神経原性腫瘍が $17 \%$ として特り，悪性 腫瘍は全体の $20 \%$ としている。本邦の報告でも多形腺腫 が37\%, 神経鞘腫が33\%, 悪性腫瘍が $14 \%$ であり, 副咽 頭間隙腫瘍は良性腫瘍が多く, なかでも多形腺腫が最多 とされている6). 一方, 悪性腫瘍では腺様囊胞癌, 多形 腺腫の悪性化が悪性腫瘍全体の 5 割近くを占め, 啧液腺 由来の腫瘍が多いと報告されている5)。本例では耳下腺 深葉由来の副咽頭間隙へ進展した悪性腫瘍と思われた。

副咽頭間隙の治療に物いて，これまでいろいろな手術 アプローチが報告されているが，Som ら4)の報告する 口内法, 頸部切開法, 経耳下腺法, 下顎骨正中離断法の 4 法, あるいはこれらの組み合わせが一般的である。口
内法は小腫瘍に対して, 頸部切開法は用手剥離できるよ らな比較的小腫瘍に適応があり，㴽かの 2 法は大きな腫 瘍に適応があるとされている。われわれは耳下腺浅葉を 剥離し顔面神経を同定確認保存した後に, 頸部切開に上 りアプローチして腫瘍を明視下にして主に用手剥離にて 腫瘍を摘出した。本例では耳下腺深葉腫瘍が副咽頭間隙 一進展した可能性が高く, そのため 1 回目の手術際し て切除断端が不十分であったことが考光られ，腺癌のた め治療効果は少ないと考光たが術後に放射線照射, 化学 療法を行った。しかし結局再発を招き，2回目の手術で 下顎部腫瘍切除ならびに耳下腺拡大全摘, 頸部郭清術を 行ったが，初回治療の手術で耳下腺全摘をあわせた一層 拡大した手術方法を考慮すべきであったと反省させられ た.

2. papillary cystadenocarcinoma そついて

以前の唾液腺癌の分類では病理組織学的に腺癌の分類 が不十分であったが，1991年にWHO は唾液腺悪性腫 瘍を18に細分した12)。 papillary cystadenocarcinoma は 卵巣に多く, 日本語訳で乳頭状囊胞腺癌といわれるよう であるが7，頭頸部領域では乳頭状囊腺癌ともいわれる ことも亦る81. 本例では初回摘出腫瘍で囊胞を有し, 病 理組織では乳頭状に增殖する腫瘍であり, 細胞の核は膿 染して抒り papillary cystadenocarcinoma と診断した. 免疫組織学的検查を行わなかったが CA19-9 と CA125 で陽性とした報告がある ${ }^{9}$. 本腫瘍は一般的に臨床的に も病理組織学的飞も低悪性といわれ, 実際Spiro ら ${ }^{10}$ は耳下腺原発の乳頭状型腺癌の多くは生存率が高い傾向 にあると述べている。矢れに対して本例では, 初診時耳 下腺深葉より進展したと思われる副咽頭間隙に腫瘍が認 められ, 初回治療後わずか 1 力月で腫瘍が龥下部に再発 して和り，手術で取り残しがあったことも否定できない がきわめて悪性度が高いと考光ることができる。

WHO では, 本腫瘍では再発は少なく低悪性度腫瘍々 しているが，本例のように再発があっても物かしくない ことを裏付沙報告として，Foss ら ${ }^{11}$ は唾液腺原発の 本腫瘍 57 例中 40 例を経過観察して, 3 例が局所再発, 注 かの 3 例が受診時にリンパ節転移を認め， 1 例が55 カ月 後にリンパ節転移したと述べ，しかも局所再発した 3 例 は耳下腺原発腫瘍であったとしている。また Pollett ら ${ }^{12)}$ は, 舌にできた高悪性度の papillary cystadenocarcinoma は, 舌切除, 両側の頸部郭清術を行ったにるかか わらず 6 カ月後に再発したとしている. 彼ら ${ }^{12)}$ はこの 
症例を高悪性度と述べて特り，こらした症例を高悪性度 と考えるのであれば本例も高悪性度としてよいと思われ る.

本腫場は, 以前考えられた以上に形態学的な幅が広く, WHO の病理組織分類のみでは確定でさない形態もある と考えられて括り，そのことが臨床上の悪性度の判定の 間違いにつながるといわれている12). 本例の病理組織に 扣いては霊胞が小さく充実成分が多かったが，悪性度が 高いことと関連があるかもしれない。

1991年の WHO の分類以前にも papillary cystadenocarcinoma と同様と考穴られる報告例があり，それらは 低悪性度の腺癌として口腔, 咽頭の小唾液腺や顎下腺原

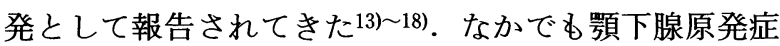
例は多く, Spiro ら ${ }^{10)}$ は唾液腺原発の papillary, muci-

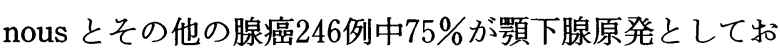
り，顎下腺原発の低悪性度の papillary cystadenocarcinoma の 22 例中 6 例で再発したとの報告もある18).耳下 腺の本腫瘍に関する再発率も含めた報告は少なく，今後 の検討が必要であると思われる.

\section{3. 診断と治療について}

われわれの症例は耳痛から始まり頸部や耳下部に明ら かな腫脹がなく, 副咽頭間隙腫瘍の診断に苦慮し治療を 受けるまでに時間を要した。確定診断がでさず経過観察 されていたことや，初回手術で腫瘍に対する十分な切除 断端がとれなかったことが再発の要因と思える. 初回手 術で確実に腫瘍を摘出できなかったことが反省点である。

また本症例では再発までの期間がわずか 1 カ月であり， 腫瘍に対する術後治療の検討も今後必要である.腫瘍を 完全に摘出でき被膜外浸潤や転移などがなければ予後は 良好であり ${ }^{19)}$ ，耳下腺内に発生した本腫瘍の報告例では 術後に放射線治療を追加し良好な結果を得たとしてい る3)19)。放射線や薬剤は有効とはいえないが，本症例で は患者の全身状態を考えて放射線治療と多剤併用治療は 行わずフルオウラシルやネダプラチンにとどめた.

また，本腫瘍のような乳頭状に増殖する腫瘍は頭頸部 領域では甲状腺にみられ，服部ら 20) は副咽頭間隙に転 移をさたした甲状腺乳頭癌の症例を報告している．本例 では超音波検查，CT，RI 検査で甲状腺腫瘍を否定した。 CEA が高値を示した症例が 2 例報告されているが8)19), 本症例では再発時に頻回測定したところ正常域であった。 一般的に唾液腺の papillary cystadenocarcinoma は低 悪性度といわれているが，今回示した症例のように完全
に全摘出しないと急速に再発, 進展することもあり注意 が必要であると考えた。

$$
\text { まとめ }
$$

1.耳下腺深葉から副咽頭間隙に進展したと思われた papillary cystadenocarcinoma の 1 例を報告した。

2. 本腫瘍は一般的に低悪性度であるが，本症例では 再発を繰り返し高悪性度と考えた。

本論文の御高閲を賜りました北里大学医学部耳鼻咽喉科学教 室高橋廣臣教授に深謝します. 本論文の要旨は第11回日本頭頸 部外科学会(2001年 1 月, 横浜)で口演した.

\section{参考文献}

1) Seifert G : Histological typing of salivary gland tumors, $2^{\text {nd }}$ ed. WHO. pp 1 112, Springer-Verlag, Berlin, 1991.

2 ) Seifert G and Sobin H : The World Health Organization's histological classification of salivary gland tumors; a commentary on the second edition. Cancer $70: 379 \sim$ $385,1992$.

3 ）望月隆一, 年田 弘, 小野淳二, 他: 耳下腺 Papillary cystadenicarcinoma 例. 耳鼻臨床 $88: 355 \sim 360,1995$.

4) Som PM, Biller HF and Lawson W : Tumors of the parapharyngeal space; preoperative evalution, diagnosis and surgical approaches. Ann Otol Rhinol Laryngol Suppl $90: 3 \sim 15,1981$.

5 ) Hughes KV 3rd, Olsen KD and McCaffrey TV : Parapharyngeal space neoplasms. Head Neck $17: 124 \sim 130$, 1995.

6 ）小田明子, 高橋裕子, 児玉 章 : 副咽頭間隙腫瘍の 1 例 一組織型，大きさと手術法について一. 耳鼻 $38: 236$ 240, 1992.

7 ) 丸山孝士 : 腫瘍各論. 新病理学 16 版 (菊池浩吉, 吉木 敬 編). 584頁, 南山堂, 東京, 1998.

8 ）伊賀弘起, 原田耕志, 川又 均, 他: 耳下腺に発症した乳 頭状囊腺癌の 1 例. 日口外誌 $42: 1109 \sim 1111,1996$.

9 ) Kobayashi I, Kiyoshima T, Ozeki S, et al. : Immunohistochemical and ultrastructural study of a papillary cystadenocarcinoma arising from the sublingual gland. J Oral Pathol Med 28 : 282 286, 1999.

10) Spiro RH, Huvos AG and Strong EW : Adenocarcinoma of salivary origin; clinicopathologic study of 204 patients. Am J Surg $144:$ 423 431, 1982.

11) Foss RD, Ellis GL and Auclair PL : Salivary gland cystadenocarcinomas ; a clinicopathological study of 57 cases. Am J Surg Pathol 20 : 1440 1447, 1996. 
12) Pollett A, Perez-Ordonez B, Jordan RC, et al. : High-grade papillary cystadenocarcinoma of the tongue. Histopathology $31: 185 \sim 188,1997$.

13) Allen MS Jr, Fitz-Hugh GS and Marsh WL Jr : Low-grade papillary adenocarcinoma of the palate. Cancer $33: 153$ $\sim 158,1974$.

14) Whittaker JS and Turner EP : Papillary tumors of the minor salivary glands. J Clin Pathol $29: 795 \sim 805,1976$.

15) Crocker TP, Kreutner A Jr, Othersen HB Jr, et al. : Papillary adenocarcinoma of minor salivary gland origin in a child. Arch Otolaryngol $109: 827 \sim 831,1983$.

16) Mills SE, Garland TA and Allen MS Jr : Low-grade papillary adenocarcinoma of palatal salivary gland origin. Am J Surg Pathol 8 : 367 374, 1984.

17) Slootweg PJ and Muller $\mathrm{H}$ : Low-grade adenocarcinoma of the oral cavity; a comparison between the terminal duct and the papillary type. J Craniomaxillofac Surg $15: 359$ 364, 1987.

18) Mostofi R, Wood RS, Christison W, et al. : Low-grade papillary adenocarcinoma of minor salivary glands ; case report and literature review. Oral Surg Oral Med Oral Pathol 73 : 591 595, 1992.

19）岸本麻子, 堤 俊之, 松本あゆみ, 他: CEA が高值を示 した耳下腺 papillary cystadenocarcinoma 例. 耳鼻 45 : 341 345, 1999.

20）服部賢二, 岩田伸子, 奥山晃子, 他：副咽頭間隙に転移を きたした甲状腺癌例. 耳鼻臨床 $93: 769 〜 773,2000$.

$$
\left.\begin{array}{l}
\text { 原稿受付 : 平成 } 13 \text { 年 } 3 \text { 月 } 5 \text { 日 } \\
\text { 原稿採択 : 平成 } 13 \text { 年 } 5 \text { 月 } 2 \text { 日 } \\
\text { 別刷請求先 : 井口芳明 } \\
\text { 个228-8555 相模原市北里 } 1-15-1 \\
\text { 北里大学医学部耳鼻咽喉科学教室 }
\end{array}\right)
$$

